Sains Malaysiana 49(9)(2020): 2301-2309

http://dx.doi.org/10.17576/jsm-2020-4909-27

\title{
Thermal Treatments on the Oil Palm Fruits: Response Surface Optimization and Microstructure Study
}

(Rawatan Termal pada Buah Kelapa Sawit: Pengoptimuman Permukaan Respon dan Kajian Struktur Mikro)

\author{
Nurul Hasimah Kasmin, Saiful Irwan Zubairi, Azwan Mat LaZim* \& RoIla Awang
}

\begin{abstract}
Sterilization is the most important steps in the palm oil milling process prior to oil extraction. Experiments involving dry heating sterilization (SD) couple with solvent extraction of palm fruits were done to determine the relationship of palm oil yield and deterioration of bleachability index (DOBI). As a comparison, the conventional method of wet heating was used (SW). The optimum sterilization treatment parameters were determined by using response surface methodology (RSM). Central composite rotatable design (CCRD) was used to study the effects of sterilization temperature, $X_{1}\left({ }^{\circ} \mathrm{C}\right)$ and treatment time, $X_{2}(\mathrm{~min})$ to oil yield $(\%)$, and DOBI. The sterilization temperature and time were conducted between 70 and $90^{\circ} \mathrm{C}$ and 20 to $90 \mathrm{~min}$, respectively. Preliminary results proved increasing temperature and time of sterilization process increased oil yield for both SD and SW. Furthermore, the DOBI showed a similar trend as the oil yield. Optimization study using SD gave the optimal response through a combination of parameters, SD: $X_{1}$ $=90{ }^{\circ} \mathrm{C}$ and $X_{2}=68 \mathrm{~min}$, where the oil yield obtained was $43.21 \%$ and DOBI 4.05. However, sterilization treatment using SW showed insignificant results ( $p>0.05$ ) between temperature and time since $R^{2}$ value was 0.4368 and the low degree of agreement between adjusted $R^{2}(0.03)$ and predicted $R^{2}(-2.43)$. It was also found SD treatment produced high $D O B I$ value though the oil yield was lower than $S W$.
\end{abstract}

Keywords: DOBI; dry heating; oil yield; RSM; wet heating

ABSTRAK

Pensterilan ialah proses utama dalam pemprosesan minyak kelapa sawit sebelum pengekstrakan untuk mendapatkan minyak sawit mentah. Uji kaji melibatkan pensterilan buah sawit menggunakan rawatan kering (SD) diikuti dengan pengekstrakan menggunakan pelarut bagi menentukan hubungan antara hasil pengekstrakan minyak sawit dan kualiti indeks pemerosotan dan pelunturan (DOBI). Kaedah konvensional menggunakan rawatan basah (SW) juga dijalankan sebagai perbandingan. Parameter pensterilan optimum ditentukan menggunakan kaedah permukaan respon (RSM). Reka bentuk berputar komposit sentral (CCRD) digunakan bagi menentukan kesan suhu, $X_{l}\left({ }^{\circ} \mathrm{C}\right)$ dan tempoh masa pensterilan, $X_{2}(\mathrm{~min})$ terhadap pengekstrakan minyak sawit (\%) dan DOBI. Suhu dan tempoh masa pensterilan dijalankan masing-masing pada 70 hingga $90^{\circ} \mathrm{C}$ dan 20 hingga 90 min. Kajian awal menunjukkan peningkatan suhu dan tempoh masa pensterilan meningkatkan hasil pengekstrakan minyak bagi kedua-dua kaedah SD dan SW. Selain itu, nilai DOBI menunjukkan tren yang sama seperti hasil pengekstrakan minyak. Kajian pengoptimuman menggunakan $S D$ memberi tindak balas optimum dengan kombinasi parameter, $S D: X_{1}=90{ }^{\circ} \mathrm{C}$ dan $X_{2}=68$ min dengan hasil pengekstrakan minyak sebanyak $43.21 \%$ dan DOBI 4.05 diperoleh. Namun, rawatan pensterilan menggunakan SW menunjukkan perbezaan yang tidak signifikan ( $\mathrm{p}>0.05$ ) antara suhu dan masa kerana nilai $R^{2}$ adalah 0.4368 dan nilai terlaras $R^{2}(0.03)$ dan telahan $R^{2}(-2.43)$ yang tidak menghampiri. Didapati rawatan SD telah menghasilkan nilai DOBI yang lebih tinggi walaupun hasil pengekstrakan minyaknya adalah lebih rendah berbanding $S W$.

Kata kunci: DOBI; pengekstrakan minyak; rawatan basah; rawatan kering; RSM

\section{INTRODUCTION}

The quality of any crude oil is related to process losses and more importantly to final product quality and stability. Quality parameters such as percentage of free fatty acids (FFA), phosphatide content, metal traces, peroxide value
$(\mathrm{PV})$, and deterioration of bleachability index (DOBI) are generally evaluated in order to determine the quality of crude palm oil (CPO) (Amir et al. 2018; Parveez et al. 2019; Tajuddin et al. 2019; Zubairi et al. 2016). DOBI is one of the quality specifications that has to be complied 
by the mill. Specification for these could contribute to quality when compared with other global palm oil standard specifications.

Besides quality, the oil extraction yield is another concern of the industry (Zubairi et al. 2014). Palm oil mills using various types of sterilization such as continuous, vertical, horizontal, and tilting. This technology is step taken in improving oil palm mill processing by increasing efficiency and reducing labour dependence. However, each technology has its own advantages compared to conventional using horizontal. Besides that, effort has been made to recover residual oil from pressed mesocarp fibre using solvent extraction. Thus, it shows that the technology used today still not effective in extracting total oil from mesocarp.

Response surface methodology (RSM) is useful tool for optimizing complex processes (Abdul Rahman et al. 2018; Liu et al. 2010). It has been successfully demonstrated that RSM can be used as a tool in optimizing the extraction of flavonoid compound (Liu et al. 2010; Mohd Azzimi et al. 2018; Mohd Fazil et al. 2016) and extraction of palm oil and olive oil (Najafian et al. 2009; Silvamany \& Jamaliah 2015). Therefore, the objective of this study was to determine the extraction of oil yield from palm mesocarp by using Soxhlet extraction with dry (SD) and wet (SW) heating treatment using RSM. Besides, the study also aimed to determine the correlation of oil yield percentage on DOBI value. Moreover, scanning electron microscopy (SEM) was utilized to ascertain the efficiency of treatment process by the increase in cell wall disruption leading to higher oil liberated.

\section{MATERIALS AND METHODS}

\section{MATERIALS}

Ripe palm fruits (Elaeis guineensis of tenera) were obtained from a local palm oil mill situated in Labu, Negeri Sembilan. The samplings were performed according to MPOB FFB Grading Manual (2003) with assistance from a certified mill FFB grader.

\section{EXPERIMENTAL DESIGN: RESPONSE SURFACE OPTIMIZATION}

With an aid of Design-Expert Version 6.0.1 software (StatEase Inc., Minneapolis, USA; Othman et al. 2017), two variables central composite rotatable design (CCRD), with five replicates run at the center point was employed to study the effect of fruits sterilization condition on oil extraction and DOBI ( $\mathrm{Y}_{1}$, oil yield; $\mathrm{Y}_{2}$, DOBI). The independent operating variables were heating parameters of the process; sterilization temperature and time, $\mathrm{X}_{1}$ and $\mathrm{X}_{2}$, which vary between 70 to $90{ }^{\circ} \mathrm{C}$ and 20 to $90 \mathrm{~min}$, respectively (Table 1). This range was suitable to deactivate the activity of the enzyme and preserve the quality of the oil.

TABLE 1. Operational conditions of heat treatment during sterilization

\begin{tabular}{ccccc}
\hline & \multicolumn{3}{c}{ Sterilization } \\
\cline { 2 - 5 } & $\mathrm{T}$ & $\mathrm{M}$ & $\mathrm{t}\left({ }^{\circ} \mathrm{C}\right)$ & $\mathrm{m}(\mathrm{min})$ \\
\hline 1 & 1 & 1 & 90 & 90 \\
2 & 1.1414 & 0 & 94 & 55 \\
3 & 0 & 0 & 80 & 55 \\
4 & -1 & -1 & 70 & 20 \\
5 & 0 & 0 & 80 & 55 \\
6 & 0 & 0 & 80 & 55 \\
7 & 0 & 0 & 80 & 55 \\
8 & -1 & 1 & 70 & 90 \\
9 & 1 & -1 & 90 & 20 \\
10 & 0 & -1.1414 & 80 & 6 \\
11 & -1.1414 & 0 & 66 & 55 \\
12 & 0 & 1.1414 & 80 & 105 \\
13 & 0 & 0 & 80 & 55 \\
\hline
\end{tabular}

$\mathrm{T} / \mathrm{t}$ : temperature $\left({ }^{\circ} \mathrm{C}\right), \mathrm{M} / \mathrm{m}$ : min. In capital letters when expressed as coded variables and small letters when expressed as actual variables 


\section{STERILIZATION OF OIL PALM FRUIT}

For each experimental run, oil fruits obtained from the mill were clean to remove any dirt on the surface, followed by heated under SD and SW treatment using electric oven and heating bath. The heated oil palm fruits were peeled, and the nuts were removed from the mesocarp. The peeled mesocarp was later extracted for its oil using soxhlet extraction.

\section{SOXHLET EXTRACTION}

The peeled mesocarp was subjected to hexane extraction by using soxhlet extractor, at fruit to solvent ratio 1:10 $(\mathrm{w} / \mathrm{v})$. The solvent was then removed from the oil by using a rotary evaporator. The yield of palm oil extract was determined using (1):

$$
\% \text { oil yield }=\frac{x}{y} \times 100 \%
$$

where, $x$ is the mass of oil extracted $(\mathrm{g})$; and is the mass of oil palm fruits $(\mathrm{g})$.

\section{DETERIORATION OF BLEACHABILITY INDEX (DOBI) ANALYSIS}

The determination of DOBI was carried out using MPOB test methods p2.9:2004. DOBI is defined as the ratio of the spectrometric absorbance at 446 to that $269 \mathrm{~nm}$. Sample $(0.1 \mathrm{~g})$ was weighed and dissolved with n-hexane in $25 \mathrm{~mL}$ volumetric flask. The absorbance was measured at 446 and $269 \mathrm{~nm}$.

\section{MICROSTRUCTURE ANALYSIS USING SCANNING ELECTRON MICROSCOPY}

A scanning electron microscope (Leo 1450VP) was used to analyze the morphology structure of mesocarp. The sample was mounted on an aluminium stub using double side adhesive tape and was coated with silver prior to the morphological and microstructural examination (Johari et al. 2017).

\section{RESULTS AND DISCUSSION}

\section{MULTIPLE RESPONSE OPTIMIZATIONS}

Based on the results obtained from the models' analyses, numerical optimization method has been used for determining the optimum condition of each sterilization operation. The desired goals for each variable and response were chosen. Accordingly, the $\mathrm{X}_{1}$ and $\mathrm{X}_{2}$ were kept within the study range while $\mathrm{Y}_{1}$ and $\mathrm{Y}_{2}$ were set to be maximized as proper CPO processing as indicated by high DOBI value and high oil yield.

Sterilization process acts as a pretreatment prior to extraction. It can be seen that cellulose (glucan) and hemicellulose (xylan and arabinan) contribute mainly to the cell wall polysaccharides constituent, followed by soluble lignin. Hemicellulose surrounds every cell of the fruit and cell of the stalk. Hemicellulose undergoes enzymatic hydrolysis, breaking down sugars at the abscission layer, allowing freeing of the fruit from bunch. Under natural situation enzymatic hydrolysis occurs when a fruit bunch is ripe or matured enough to be affected by chemical changes due to weather (hot or wet period) and chemicals; fertilizer applications to the palm trees (Ariffin 2018). Thus, to facilitate the release of oil located in the vacuole and cytoplasmic membranes, it is essential to degrade and rupture the cellular wall of fruit mesocarp. Sterilization provides a very conducive chemical environment that quickens ruptured of cell wall, thus release oil from oil globule.

In this study, oil yield obtained ranged from 33.96 to $46.12 \%$, with minimum and maximum values were recorded from $\mathrm{CPO}$ extracted from SW treatment. The minimum to maximum ranges obtained from the overall 13 experimental runs was represented in Figure 1. The recorded data show that both types of sterilization treatment produces high oil extraction yield. However, $\mathrm{SD}$ varied in a narrow extraction yield range compared to SW due to the loss of oil during SW treatment. In fact, the increase in sterilization time will increase disintegration and the release of the cell contents with traces of fiber

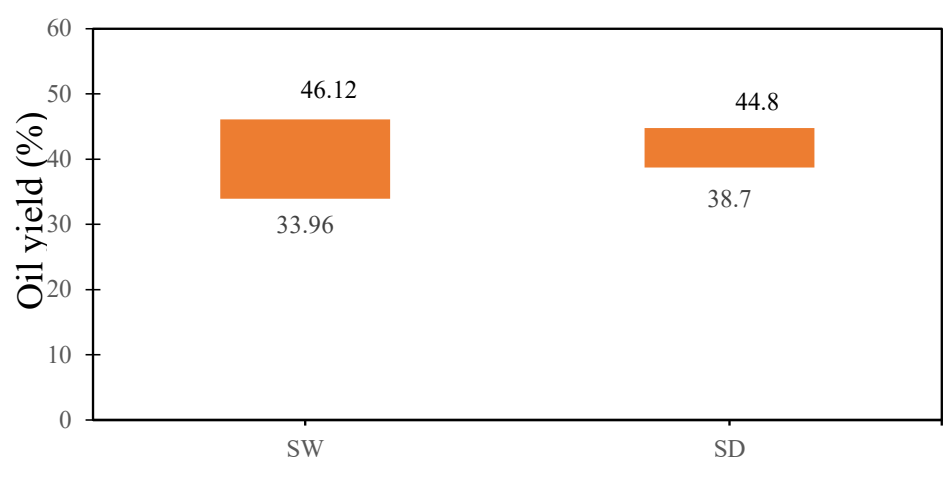

Sterilization treatment

FIGURE 1. Oil yield value (minimum to the maximum range) for $\mathrm{CPO}$ extracted from $\mathrm{SD}$ and $\mathrm{SW}$ 
and crystals (Owolarafe \& Faborode 2008; Pootao \& Kanjanapongkul 2016). The viscosity of oil also lower, thus assist in oil flow to the water in SW treatment.

The oil extraction yield obtained from 13 experimental runs and respective predicted values from SD treatment were summarized in Table 2. However, sterilization treatment using SW showed insignificant results $(p>0.05)$ between temperature and time since $\mathrm{R}^{2}$ value was 0.4368 and the low degree of agreement between adjusted $R^{2}(0.03)$ and predicted $R^{2}(-2.43)$. For
SD, the highest oil yield predicted was $44.51 \%$ recorded by run $2\left(94^{\circ} \mathrm{C}\right.$ and $\left.55 \mathrm{~min}\right)$. Optimum research using SD treatment show optimum response by a combination of the parameter, temperature $\mathrm{SD}: \mathrm{X}_{1}=90^{\circ} \mathrm{C}$ and time $\mathrm{SD}: \mathrm{X}_{2}=$ 68 min where CPO extracted obtained was $43.21 \%$ (w/w). The regression model equation was shown in equation (2) and (3). The experimental results were subjected to model fitting, where polynomial regression models will explain the effect of sterilization on oil yield.

TABLE 2. Central composite design and experiment data of SD treatment

\begin{tabular}{|c|c|c|c|c|c|c|}
\hline \multirow{2}{*}{ Run } & \multicolumn{2}{|c|}{ Sterilization } & \multicolumn{2}{|c|}{ Oil extraction yield $(\% \mathrm{w} / \mathrm{w})$} & \multicolumn{2}{|c|}{ DOBI } \\
\hline & Temperature $\left({ }^{\circ} \mathrm{C}\right)$ & $\begin{array}{l}\text { Time } \\
(\mathrm{min})\end{array}$ & Experimental value (\%) & Predicted value $(\%)$ & $\begin{array}{l}\text { Experimental } \\
\text { value }\end{array}$ & $\begin{array}{c}\text { Predicted } \\
\text { value }\end{array}$ \\
\hline 1 & 90 & 90 & 43.35 & 43.55 & 4.10 & 3.96 \\
\hline 2 & 94 & 55 & 44.80 & 44.51 & 3.83 & 4.08 \\
\hline 3 & 80 & 55 & 39.00 & 40.20 & 3.55 & 3.77 \\
\hline 4 & 70 & 20 & 38.74 & 39.32 & 2.86 & 2.78 \\
\hline 5 & 80 & 55 & 42.49 & 40.20 & 3.80 & 3.77 \\
\hline 6 & 80 & $55 Z Z$ & 39.07 & 40.20 & 3.81 & 3.77 \\
\hline 7 & 80 & 55 & 40.19 & 40.20 & 3.87 & 3.77 \\
\hline 8 & 70 & 90 & 38.81 & 39.15 & 3.85 & 3.91 \\
\hline 9 & 90 & 20 & 40.43 & 40.87 & 3.58 & 3.30 \\
\hline 10 & 80 & 6 & 38.70 & 38.14 & 2.25 & 2.46 \\
\hline 11 & 66 & 55 & 40.80 & 40.31 & 3.70 & 3.67 \\
\hline 12 & 80 & 105 & 40.14 & 39.92 & 3.73 & 3.74 \\
\hline 13 & 80 & 55 & 40.24 & 40.20 & 3.81 & 3.77 \\
\hline
\end{tabular}

Table 3 shows the fit summary report of models that summarizing results of following model sum of squares (SS) and lack of fit (LOF) test, including regression coefficient $\left(\mathrm{R}^{2}\right)$ values. The sequential model SS was analyzed for testing the hypotheses of model parameters. The ultimate aim of sequential analysis is to select the highest degree of non-aliased model that has a $p$-value of additional terms that is lower than the chosen level of significance (Montgomery 2001). The $p$-value approach was used for the testing. If the $p$-value is less than 0.05 , it rejects the null hypothesis, $\mathrm{H}_{0}$ and thus concludes that at least one of the two parameters has significant terms estimating the factor effects.
The LOF test results are useful to indicate the reliability of the model (Bas \& Boyaci 2007). If the $p$-value obtained from this test is less than 0.05 , then LOF is significant. The model is reliable with no significant LOF. Regression Coefficient, $\mathrm{R}^{2}$ is a measure of the amount of variation around the mean explained by the model, which also known as a degree of fit measurement that is beneficial for measuring the proportion of total variability explained by the model. The high $\mathrm{R}^{2}$ value that is closer to 1.0 and not less than 0.8 indicates a good model fitting (Montgomery 2001). A value of 1.0 represents the ideal case at which the chosen model can explain $100 \%$ of the variation in the observed values. Predicted $\mathrm{R}^{2}$ should be in reasonable agreement with the adjusted $\mathrm{R}^{2}$ (within 0.20 of each other). 
TABLE 3. Summary report for fitting models

\begin{tabular}{lllllll}
\hline \multirow{2}{*}{ Response } & Model & \multicolumn{2}{l}{ SS } & \multicolumn{2}{l}{ LOF } & \multicolumn{2}{l}{ Model summary statistics } \\
\cline { 3 - 6 } & LNR & $p$-value & $p$-value & $\mathrm{R}^{2}$ & Adj. $\mathrm{R}^{2}$ & Pred. $\mathrm{R}^{2}$ \\
\hline $\mathrm{Y}_{1}$ & 0.0424 & 0.4140 & 0.4685 & 0.3622 & 0.0240 \\
& 2FI & 0.0778 & 0.3916 & 0.5141 & 0.3522 & 0.1082 \\
& QRC & 0.0252 & 0.8725 & 0.7902 & 0.6403 & 0.5019 \\
$\mathrm{Y}_{2}$ & LNR & 0.0098 & 0.0157 & 0.6032 & 0.5238 & 0.1978 \\
& 2FI & 0.5223 & 0.0128 & 0.6218 & 0.4958 & 0.1707 \\
\hline
\end{tabular}

$* \mathrm{LNR}=$ linear; $2 \mathrm{FI}=$ Two factor interaction; $\mathrm{QRC}=$ quadratic

The quadratic model is the most appropriate model for both $\mathrm{Y}_{1}$ and $\mathrm{Y}_{2}$ due to lowest $p$-value of $<0.0252\left(\mathrm{Y}_{1}\right)$ and $0.0077\left(\mathrm{Y}_{2}\right)$ in sequential analysis and shows a significant difference. The quadratic model showed insignificance of LOF with the highest $p$-value, $0.8725\left(\mathrm{Y}_{1}\right)$ and 0.0867 $\left(\mathrm{Y}_{2}\right)$ as compared to the LNR dan 2FI model with 0.4140 and 0.3916 for oil yield and 0.6032 and 0.4958 for DOBI, respectively. Besides, the quadratic model recorded the highest $\mathrm{R}^{2}$ and was the only value with $\mathrm{R}^{2}, 0.8$. Once the selected models were fitted, ANOVA was performed onto individual fitted models to examine the statistical significance of the model terms. ANOVA data have been summarized in Table 4.

TABLE 4. ANOVA of the operational condition during sterilization

\begin{tabular}{llllll}
\hline Source & Sum of square & Degree of freedom & Mean square & F value & Prob $>$ F \\
\hline Model & 35.12 & 5 & 7.02 & 5.27 & $0.0252^{\mathrm{s}}$ \\
$\mathrm{X}_{1}$ & 17.66 & 1 & 17.66 & 13.26 & 0.0083 \\
$\mathrm{X}_{2}$ & 3.16 & 1 & 3.16 & 2.37 & 0.1676 \\
$\mathrm{X}_{1}^{2}$ & 8.52 & 1 & 8.52 & 6.39 & 0.0393 \\
$\mathrm{X}_{2}^{2}$ & 2.37 & 1 & 2.37 & 1.78 & 0.2243 \\
$\mathrm{X}_{1} \mathrm{X}_{2}$ & 2.03 & 1 & 2.03 & 1.52 & 0.2568 \\
Residual & 9.33 & 7 & 1.33 & & $0.8725^{\mathrm{ns}}$ \\
Lack of Fit (LOF) & 1.36 & 3 & 0.45 & 0.23 & \\
Standard deviation $=1.15$, & & & & & \\
adequate precision $=8.12$ & & & & & \\
\hline
\end{tabular}

$\mathrm{s}=$ significant $\mathrm{ns}=$ not significant

The models also found with relatively low standard deviation (1.15), high adequate precision (8.123) as well as achieving reasonable agreement between adjusted and predicted $\mathrm{R}^{2}$. Adequate precision measures the signal to noise ratio. If the ratio is found as greater than four, it indicates an adequate signal. Thus, particular model can be used to navigate the design space (Bas \& Boyaci 2007). The term $X_{1}$ and $X_{1}^{2}$ contributed significant effects to oil extraction yield with a $p$-value less than 0.05 . 
On the contrary, the term $\mathrm{X}_{2}, \mathrm{X}_{2}^{2}$ and combination of $\mathrm{X}_{1} \mathrm{X}_{2}$ were insignificant. Hence, we can conclude that temperature plays the most important role in maximizing the release of oil than the time of sterilization. The quadratic model equation for coded and actual equation was shown in (2) and (3).

$\mathrm{Y}_{1} \mathrm{coded}=40.20+1.49 \mathrm{X}_{1}+0.63 \mathrm{X}_{2}+1.11 \mathrm{X}_{1}{ }^{2}-$ $0.58 \mathrm{X}_{2}^{2}+0.71 \mathrm{X}_{1} \mathrm{X}_{2}$

$\mathrm{Y}_{1}$ actual $=105.66437-1.73398 \mathrm{X}_{1}-0.092521 \mathrm{X}_{2}+0.01106 \mathrm{X}_{1}{ }^{2}$ $4.76224^{\mathrm{e}-004} \mathrm{X}_{2}^{2}+2.03571^{\mathrm{e}-003} \mathrm{X}_{1} \mathrm{X}_{2}$

Figure 2(a) and 2(b) shows interaction between independent and dependent variables of the response surface generated by the fitted models equations. These figures represent the oil extraction yield of $\mathrm{CPO}$ as a function of sterilization temperature and time, which are useful for understanding the main effects of temperature and time of sterilization. The temperature of sterilization significantly affected the quantity of extracted CPO as can be seen by comparing experiments 11 and 2 (Table
2), which offer maximum and nearly minimum values for oil extraction yield. The yield increases with a higher temperature and longer heating time. Similar results were also found by other researchers (Baryeh 2001; Pootao \& Kanjanapongkul 2016).

However, changes in cell microstructure are usually an indication of the lose in cell arrangement and disruption of the cell wall through temperature increase up to $80^{\circ} \mathrm{C}$ (Owolarafe \& Faborode 2008; Pootao \& Kanjanapongkul 2016). In fact, extraction of CPO is greater than $42 \%$ obtained when processing temperature exceeds $85{ }^{\circ} \mathrm{C}$ and time $55 \mathrm{~min}$ and above. The findings suggested that the extraction of $\mathrm{CPO}$ at $90{ }^{\circ} \mathrm{C}$ only needs $55 \mathrm{~min}$ to achieve maximum oil recovery. The lowest extraction of CPO is predicted with the use of temperature and time of processing below $85{ }^{\circ} \mathrm{C}$ and $55 \mathrm{~min}$. Besides, prolong heating period exceed $70 \mathrm{~min}$ with the use of temperature below $85^{\circ} \mathrm{C}$ also will obtain lower oil yield. This is due to increasing temperature that might accelerate the hydrolysis of cellulose and hemicellulose molecules and ruptured the cell wall of the samples thus facilitating oil extraction. (a)

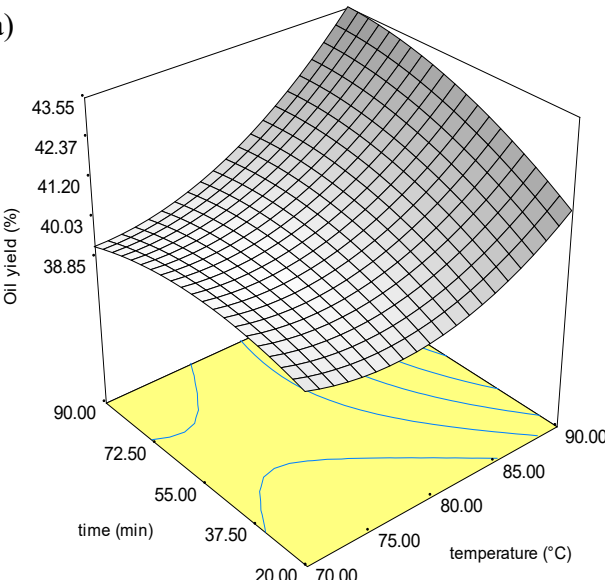

(c)

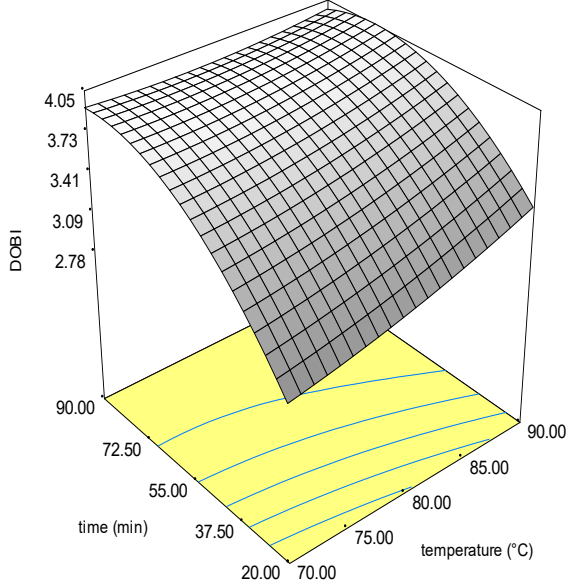

(b)



(d)

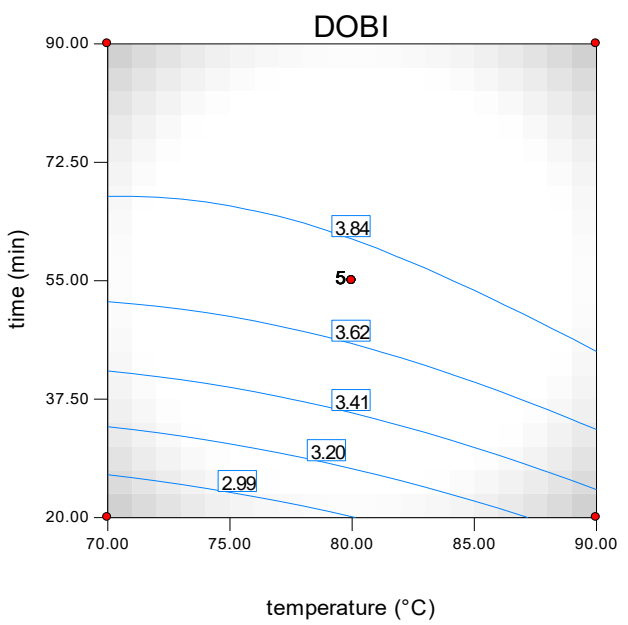

FIGURE 2. Effect of processing temperature and time on oil yield (a) and (b), DOBI (c) and (d) 
$\mathrm{Y}_{2}$ coded $=3.77+0.14 \mathrm{X}_{1}+0.45 \mathrm{X}_{2}+0.054 \mathrm{X}_{1}^{2}-0.33 \mathrm{X}_{2}^{2}-$ $0.12 \mathrm{X}_{1} \mathrm{X}_{2}$

For DOBI, as can be observed in Figure 2(c)-2(d) and equation (4), the linear coefficient for processing temperature, $\left(\mathrm{X}_{1}\right)$ has a lesser effect compared to time. Thus, it indicates that there was a significant effect of a linear factor of time $\left(\mathrm{X}_{2}\right)$ on the DOBI. This result is approving the previous findings made by Junaidah et al. (2015) that the change in processing temperature seemed to be less significant than the change in processing time. This might be due to the fruits starts to ripen and each fruit contained almost similar carotene content. It was also observed that DOBI showed the same trend as oil yield when processing time increased. Thus, it shows that higher oil yield will produce better DOBI. A higher amount of oil indicates the extraction process is effective in withdrawing solute from solid matrices that contain the interest compound (Mohd Azizi et al. 2015) thus not just oil globule, carotene compounds also being extracted from the palm fruits.

\section{MICROSTRUCTURE ANALYSIS}

SEM micrographs indicate a very rigid and organized cell structure of fresh mesocarp as illustrated in Figure 3(a) along with treated mesocarp in Figure 3(b)-3(e). Both type of heating as a pretreatment process promotes degradation of some cell walls. Increase in cell wall disintegration leading to a higher release of oil. In this study, there was no significant difference between the two samples and this was confirmed by the results of oil yield. Untreated mesocarp has smoother cell walls, and treated samples have an irregular surface and less structured. Besides, a thinning effect on the walls also noticeable.

Both treatments recorded almost the same thickness size of cell walls, as depicted in Table 5. However, the surface of SW was found more oily compared to SD. The oil clumped, and the cell wall was swollen. Thus, this implies that SW appeared to be more hydrated than $\mathrm{SD}$, while the cell arrangement in SD tends to be more compact and dense. The surface of treated mesocarp (Figure 3(d)-3(e)) after soxhlet extraction was found very smooth with no deposited of oil. The presence of silica is seen from Figure 3(d). It shows that $6 \mathrm{~h}$ of extraction is sufficient to extract the oil. Meanwhile, for Figure 3(e), more severe rupture of the cell wall and leaving pore structure. However, this takes more than $24 \mathrm{~h}$ to occur.
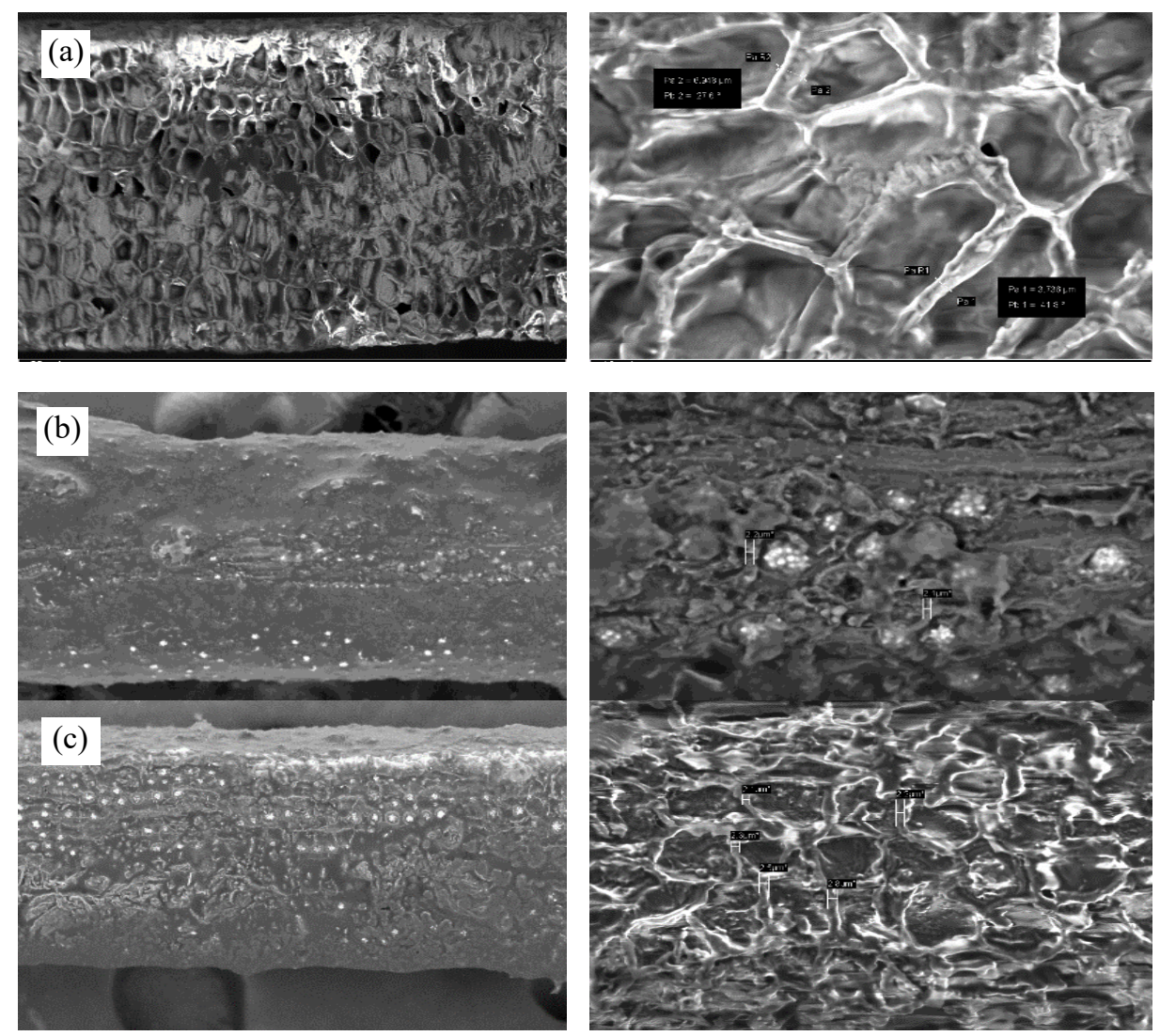

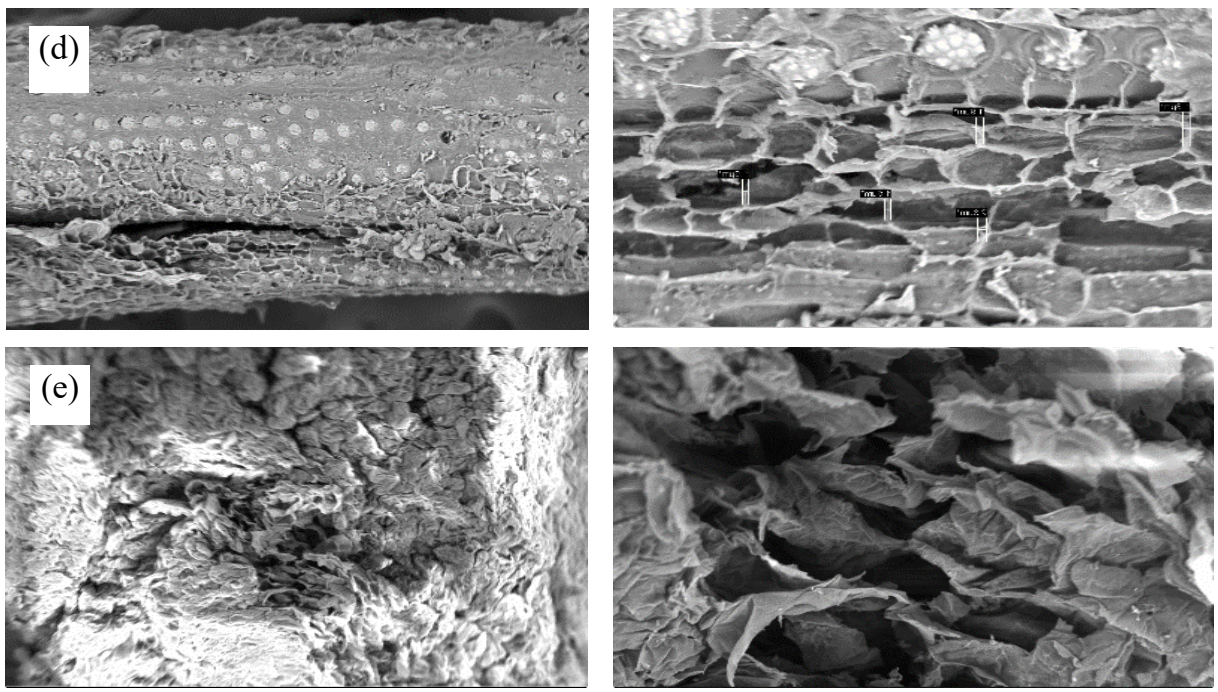

FIGURE 3. SEM micrograph of raw mesocarp (a), mesocarp after SW (b), SD (c), SD and soxhlet extraction for $6 \mathrm{~h}$ (d),

SD and soxhlet extraction until colourless (e) at $90{ }^{\circ} \mathrm{C}$ and 90 $\min ($ magnification $100 \times$ and $500 \times$ )

TABLE 5. Thickness of cell wall at different treatment

\begin{tabular}{cc}
\hline Sample mesocarp & The thickness of cell wall $(\mu \mathrm{m})$ \\
\hline Raw sample & 4.4 \\
SW sample & 2.2 \\
SD sample & 2.3 \\
\hline
\end{tabular}

\section{CONCLUSION}

From the experiments conducted, the lower temperatures apply during sterilization process compared to current practice in industrial shows a high oil yield and DOBI value. In this study, the optimum study using SD gave the optimal response through a combination of parameters, SD: $\mathrm{X}_{1}=$ $90{ }^{\circ} \mathrm{C}$ and $\mathrm{X}_{2}=68 \mathrm{~min}$, where the oil yield obtained was $43.21 \%$ and DOBI 4.05. However, sterilization treatment using SW showed insignificant results $(p>0.05)$. It was also found SD treatment produced high DOBI value than SW even though the oil yield was lower. Besides, the morphology of the two treatments appeared almost the same. Therefore, it could be concluded that the SW and SD treatment have no difference in oil yield, DOBI, and microstructure obtained. The results imply that SD treatment can also be an alternative treatment for oil palm pretreatment to eliminate the production of mill effluent by the industry.

\section{ACKNOWLEDGEMENTS}

The authors would like to express their gratitude to the Malaysian Palm Oil Board (MPOB) and Universiti Kebangsaan Malaysia (UKM) for the financial support (GUP-2018-057) and technical assistance to conduct this study. The help and assistant from the staff of the Electron Microscopy Unit are greatly acknowledged and appreciated.

\section{REFERENCES}

Abdul Rahman, N.F., Harun, S., Sajab, M.S., Zubairi, S.I., Md Jahim, J., Markom, M., Nor, M.T.M., Abdullah, M.A. \& Hashim, N. 2018. Boosting enzymatic hydrolysis of pressurized ammonium hydroxide pretreated empty fruit 
bunch using response surface methodology. Journal of Engineering Science and Technology (JESTEC) 13(8): 24212445.

Amir, U.A., Md Jamil, M.S. \& Zubairi, S.I. 2018. Optimization of noodle formulation using empty fruit bunch palm oil carboxymethyl cellulose (CMC) and different types of flour. Jurnal Teknologi (Sciences and Engineering) 80(5): 45-56.

Ariffin, A.A. 2018. Rapid equilibrated high-pressure sterilization technology to quicken and to complete the detachment of every fruit from fresh fruit bunches (FFB) for better oil recovery. National Seminar on Palm Oil Milling, Refining, Environment and Quality. Organized by Malaysian Palm Oil Board. The Royale Chulan Hotel, Kuala Lumpur.

Bas, D. \& Boyaci, I.H. 2007. Modeling and optimization I: Usability of response surface methodology. Journal of Food Engineering 78(3): 836-845.

Baryeh, E.A. 2001. Effects of palm oil processing parameters on yield. Journal of Food Engineering 48(1): 1-6.

Fresh Fruit Bunch (FFB) Grading Manual. 2003. Kuala Lumpur: Malaysian Palm Oil Board.

Junaidah, M.J, Norizzah, A.R. \& Zaliha, O. 2013. Effect of sterilization process on deterioration of bleachability index (DOBI) of crude palm oil (CPO) extracted from different degrees of oil palm ripeness. International Journal of Bioscience, Biochemistry and Bioinformatics 3(4): 322-327.

Johari, N.S.C., Aizad, S. \& Zubairi, S.I. 2017. Efficacy study of carrageenan as an alternative infused material (filler) in poly(3-hydroxybutyrate-co-3-hydroxyvalerate) (phbv) porous 3-d scaffold. International Journal of Polymer Science 2017: Article ID. 5029194.

Liu, W., Yu, Y., Yang, R., Wan, C., Xu, B. \& Cao, S. 2010. Optimization of total flavonoid compound extraction from Gynura medica leaf using response surface methodology and chemical composition analysis. International Journal Molecule Science 11(11): 4750-4663.

Mohd Azizi, C.Y., Zuhaili, I., Jeffry, J., Muhammad Shafiq Hazwan, R., Nor Azian, M. \& Liza, M.S. 2015. Extraction of beta carotene from palm mesocarp via green sub-critical carbon dioxide. Jurnal Teknologi (Science \& Engineering) 74(7): 35-39.

Mohd Azzimi, N.S., Mohd Fazil, F.N. \& Zubairi, S.I. 2018. Response surface optimization on the phenolic content and antioxidant activities of Sabah Snake Grass (Clinacanthus nutans) leaves extract. International Food Research Journal 25(Suppl. 1): S105-S115.

Mohd Fazil, F.N., Mohd Azzimia, N.S., Yahaya, B.H., Kamalaldin, N.A. \& Zubairi, S.I. 2016. Kinetics extraction modelling and antiproliferative activity of Clinacanthus nutans water extract. The Scientific World Journal 2016: Article ID. 7370536.

Montgomery, D.C. 2001. Design and Analysis of Experiments. Fifth Edition. New York: Wiley.

Najafian, L., Ghodsvali, A., Khodaparast, M.H.H. \& Diosady, L.L. 2009. Aqueous extraction of virgin olive oil using industrial enzymes. Food Research International 42(1): 171-175.

Othman, Z.S., Hasan, N.S. \& Zubairi, S.I. 2017. Response surface optimization of rotenone using natural alcohol-based deep eutectic solvent as additive in the extraction medium cocktail. Journal of Chemistry 2017: Article ID. 9434168.

Owolarafe, O.K. \& Faborode, M.O. 2008. Micro-structural characterization of palm fruit at sterilization and digestion stages in relation to oil expression. Journal of Food Engineering 85(4): 598-605.

Parveez, G.K.A., Tarmizi, A.H.A., Alias, H. \& Ahmad, K. 2019. Palm oil sterilization technologies and their implication on oil loss, quality and food safety. International Planters Conference by Malaysian Palm Oil Board (MPOB). Accessed on 15-16 July 2019.

Pootao, S. \& Kanjanapongkul, K. 2016. Effects of ohmic pretreatment on crude palm oil yield and key qualities. Journal of Food Engineering 190: 94-100.

Silvamany, H. \& Jamaliah, M.J. 2015. Enhancement of palm oil extraction using cell wall degrading enzyme formulation. Malaysian Journal of Analytical Sciences 19(1): 77-87.

Tajuddin, N.A., Harun, S., Sajab, M.S., Zubairi, S.I., Jahim, J.M., Markom, M., Nor, M.T.M., Abdullah, M.A. \& Hashim, N. 2019. Influence of deep eutectic solvent (DES) pretreatment on various chemical composition of empty fruit bunch (EFB). International Journal of Engineering and Technology 8(1.2): 266-274.

Zubairi, S.I., Mantalaris, A., Bismarck, A. \& Aizad, S. 2016. Polyhydroxyalkanoates (PHAs) for tissue engineering applications: Biotransformation of palm oil mill effluent (POME) to value-added polymers. Jurnal Teknologi (Sciences and Engineering) 78(1): 13-29.

Zubairi, S.I., Sarmidi, M.R. \& Aziz, R.A. 2014. The effects of raw material particles size, types of solvents and solvent-to-solid ratio on the yield of rotenone extracted from derris roots. Sains Malaysiana 43(5): 707-713.

Nurul Hasimah Kasmin \& Saiful Irwan Zubairi

Department of Food Sciences

Faculty of Science and Technology

Universiti Kebangsaan Malaysia

43600 UKM Bangi, Selangor Darul Ehsan

Malaysia

Azwan Mat Lazim*

Department of Chemical Sciences

Faculty of Science and Technology

Universiti Kebangsaan Malaysia

43600 UKM Bangi, Selangor Darul Ehsan

Malaysia

Roila Awang

Engineering \& Processing Research Division

Malaysian Palm Oil Board

No. 6, Persiaran Institusi, Bandar Baru Bangi

43000 Kajang, Selangor Darul Ehsan

Malaysia

*Corresponding author; email: azwanlazim@ukm.edu.my

Received: 15 October 2019

Accepted: 8 May 2020 